\title{
Nowotwór piersi - problemy i jakość życia kobiet po mastektomii
}

\author{
Breast cancer - problems and quality of women's life after \\ mastectomy
}

\author{
KAROLINA CIECHANOWSKA ${ }^{1}$, KAROLINA KRAJEWSKA ${ }^{1}$, ANNA \\ ANTCZAK-KOMOTERSKA ${ }^{1}$
}

\author{
1Studenckie Koło Naukowe Nauk o Zdrowiu, Instytut Nauk o Zdrowiu PWSZ we \\ Włocławku, opiekun Koła: dr Beata Haor \\ 2 Instytut Nauk o Zdrowiu, PWSZ we Włocławku \\ DOI: http://dx.doi.org/10.21784/IwP.2018.024 \\ ISSN: 2451-1846
}

\section{Streszczenie:}

Wstęp. Rak piersi jest jednym z najczęściej odnotowywanych przypadków nowotworów wśród kobiet. Profilaktyka oraz zdrowy styl życia stwarzają szansę na unikanie radykalnej formy leczenia jaką jest mastektomia.

Cel. Celem pracy jest przegląd piśmiennictwa obejmujący zakres promocji zdrowia, profilaktyki oraz sposobu radzenia sobie kobiet po chirurgicznym usunięciu piersi.

Przegląd. Szereg czynników sprzyja rozwojowi raka piersi. Bardzo istotnym aspektem profilaktyki jest potęgowanie zachowań prozdrowotnych wśród kobiet, co sprzyja zmniejszeniu ryzyka wystąpienia choroby. Mastektomia jest jedną z wielu metod leczenia raka piersi. Jakość życia kobiet po mastektomii ulega znacznej zmianie. Najczęściej występującym problemem jest brak akceptacji własnej osoby, zmienionego obrazu ciała.

Wnioski. Dane statystyczne wskazują na przyrost liczby zachorowań i zgonów z powodu raka piersi. Wyniki badań wśród kobiet po mastektomii wskazują na ogromne zmiany w sferze psychicznej oraz fizycznej ich funkcjonowania. 
Słowa kluczowe: nowotwór piersi, mastektomia, profilaktyka

\section{Abstract:}

Introduction. Breast cancer is one of the most frequently reported cases of cancer among women. Prevention and a healthy lifestyle offer a significant opportunity to avoid mastectomy which is the most radical form of treatment.

The aim. The aim of the work is to present the review of literature on health promotion, prevention and the way women cope with everyday life after surgical removal of the breast.

Overview. A number of factors contribute to the development of breast cancer. A crucial aspect of prevention is the enhancement of pro-health behaviors among women, which helps to reduce the risk of disease. Mastectomy is one of many methods of treatment for breast cancer. The quality of life of women after mastectomy is significantly affected. The most common problem is the lack of self-acceptance, a changed body image.

Conclusions. Statistics show a substantial increase in the burden of cancer and the number of deaths from breast cancer. The results of the research among post-mastectomy women indicate huge changes in the mental and physical sphere of their functioning.

Keywords: breast cancer, mastectomy, prevention

\section{Wstęp}

Rak piersi zaraz po nowotworze płuca jest najczęściej odnotowywanym nowotworem wśród płci żeńskiej [1].

Nowotworem nazywamy niekontrolowany rozrost komórek, który podlega licznym modyfikacjom w kodzie genetycznym. Może on przyjmować postać łagodną oraz złośliwą [2]. Nowotwór złośliwy daje przerzuty do innych narządów, co często ma miejsce w przypadku raka piersi. Szacuje się, że na świecie występuje $23 \%$ zachorowań na ten typ raka a $14 \%$ kobiet umiera $\mathrm{z}$ tego powodu [3]. Na rycinie 1 przedstawiono zachorowalność na nowotwór piersi w grupie kobiet w Polsce. 
Rycina 1. Zachorowalność kobiet na nowotwór piersi powyżej 30 roku życia w latach 2010-2015.

Źródło: Krajowy Rejestr Nowotworów

Dane statystyczne pochodzące $\mathrm{z}$ Krajowego Rejestru Nowotworów przedstawiają tendencję wzrostową zachorowalności na nowotwór piersi w Polsce. W 2010 roku odnotowano 15709 nowych przypadków, natomiast trzy lata później zostało zarejestrowanych aż 1353 przypadków więcej. Podobnie wygląda to w roku 2015, gdzie liczba zachorowań wynosi 18017, co świadczy o ty, że aż 955 kobiet więcej usłyszało negatywną diagnozę. Rycina 2 prezentuje zgony z powodu raka piersi (rycina 2).

Rycina 2. Zgony kobiet z powodu nowotworu piersi powyżej 30 roku życia w latach 2010-2015.

Źródło: Krajowy Rejestr Nowotworów 
Krajowy Rejestr Nowotworów w prezentowanych danych statystycznych wskazuje na rosnącą liczbę zgonów z powodu raka piersi w Polsce. W 2010 roku zmarło z tego powodu aż 5184 kobiet, w 2013 roku o 592 więcej. Natomiast po 2 latach (2015 rok) odnotowano ponowny przyrost - 500 kolejnych nowych zgonów z powodu raka piersi, co wskazuje na bardzo niepokojący trend w populacji Polek (rycina 2).

Przyczyn powyższej sytuacji należy upatrywać w dużej mierze w prezentowanych zachowaniach zdrowotnych. Według Światowej Organizacji Zdrowia to prowadzony przez populację styl życia wpływa w 50\% na ukształtowanie się zdrowia w przyszłości, w 20\% decydują o tym uwarunkowania środowiskowe, podobnie jak czynniki genetyczne. Natomiast tylko w $10 \%$ powyższa sytuacja to efekt oddziaływań a właściwie ich niedostatku ze strony opieki zdrowotnej [4].

Celem artykułu jest przedstawienie zwiększającego się problemu zachorowalności i umieralności na nowotwór piersi oraz ukazanie istotnych zmian, jakie następują $\mathrm{w}$ życiu kobiety po mastektomii na podstawie analizy literatury.

\section{Przegląd literatury}

Czynnikiem ryzyka nowotworu złośliwego można nazwać sytuację, która przyczyni się do jego powstania. Uwarunkowania w tym zakresie obejmują szereg elementów [5]. W przypadku zachorowania na nowotwór piersi wymienić należy m.in.:

-przebytą chorobę nowotworową piersi, -otyłość,

- nadmierną objętość piersi,

-narażenie na promieniowanie jonizujące,

-wystąpienie nowotworu piersi u bliskiej rodziny (matka, siostra), -wiek $\geq 50$ lat podnosi ryzyko zachorowania, -zbyt późną menopauzę u kobiet, 
-wczesne pokwitanie,

-dziedziczność (ok. 5\% przypadków),

-długotrwałe stosowanie antykoncepcji hormonalnej,

-spożywanie nadmiernej ilości tłuszczu zwierzęcego,

-nadciśnienie tętnicze oraz cukrzycę,

-łagodne odmiany chorób piersi (np. włókniak) [2].

W ramach działań profilaktycznych zmniejszających ryzyko zachorowania na raka piersi należy podkreślić konieczność modyfikacji dotychczasowych zachowań zdrowotnych poprzez: systematyczną aktywność fizyczną, spożywanie małej ilości alkoholu, ograniczenie soli $\mathrm{w}$ diecie, racjonalne odżywianie się $\mathrm{z}$ uwzględnieniem 5 posiłków dziennie, $\mathrm{w}$ tym koniecznie $\mathrm{z}$ udziałem owoców i warzyw, które są źródłem błonnika [6]. Zmniejszenie liczby zgonów z powodu raka piersi wynika także z wczesnego rozpoznania nowotworu (samobadanie, USG piersi, mammografia, biopsja) i podjęcia odpowiedniej terapii. Wczesne wykrycie choroby nowotworowej daje szansę na jej całkowite wyleczenie, co jest możliwe dzięki regularnym badaniom profilaktycznym [7].

Narodowy Programu Zwalczania Chorób Nowotworowych na lata 2016-2024 w Polsce zakłada promowanie zdrowego stylu życia wśród populacji wraz z szerzeniem świadomości istotnej roli częstych badań profilaktycznych, które pozwolą zapobiec chorobie nowotworowej. W ramach akcji informacyjnej są np. rozsyłane ulotki oraz rozwieszane plakaty $\mathrm{w}$ wojewódzkich oddziałach Narodowego Funduszu Zdrowia i Państwowej Inspekcji Sanitarnej, centrach onkologii oraz fundacjach, podmiotach leczniczych. Materiały te informują o dostępności badań profilaktycznych i sposobach zmniejszenia ryzyka zachorowania na nowotwory. Program przewiduje także m.in. wyposażenie szpitali w specjalistyczny sprzęt, który umożliwi leczenie chorób nowotworowych. Z kolei Program Profilaktyki Raka Piersi ma zachęcić kobiety do wykonywania bezpłatnej mammografii $[8,9]$. 
Do niepokojących objawów w obrębie gruczołu piersiowego, które wymagają kontroli onkologa lub ginekologa nadmienić należy przede wszystkim:

- wyczuwalny guz,

- krwisty wyciek z brodawki,

- wciągniętą brodawkę,

- stwardnienie skóry,

- owrzodzenie w obrębie brodawki,

- zgrubienie skóry piersi,

- wciągnięcie skóry,

- pojawienie się tak zwanej „skórki pomarańczy”,

- wyczuwalne zmiany struktury i rozmiaru węzłów chłonnych [2].

Mastektomia to jedna z metod leczenia raka piersi. Amputacja gruczołu piersiowego jest najczęściej stosowana, gdy guz ma powyżej 3 centymetrów [2]. Jest to wielkie przeżycie dla każdej kobiety, które może prowadzić do zaburzenia obrazu siebie. Najczęściej przejawia się to obniżeniem nastroju, poczuciem braku wartości w społeczeństwie. Negatywne myślenie skutkuje również odizolowaniem się od najbliższych, agresywnym reagowaniem na dotyk, unikaniem rozmów [10]. Zaburzenie w sferze psychicznego funkcjonowania po mastektomii może wynikać także z bólu - odczuwa go $20-30 \%$ pacjentek. Wynika to $\mathrm{z}$ powikłań pooperacyjnych (przerwanie nerwu międzyżebrowo-ramiennego). Dolegliwości bólowe uniemożliwiają kobiecie prawidłowe funkcjonowanie [11].

Badania przeprowadzone przez M. Pawlik i B. KarczmarekBorowską na temat akceptacji choroby nowotworowej wśród 54 kobiet po mastektomii, wskazują na brak ich prawidłowej adaptacji do zmienionej sytuacji, wynikającej $\mathrm{z}$ usunięcia piersi. Zaburzeniu podlegała bowiem nie tylko sfera ich fizycznego funkcjonowania, ale także sfera psychiczna, co może prowadzić do rozwoju depresji. Jak wskazują wyniki badań przystosowanie pacjentek do nowej sytuacji nie zależało od wykonywanej pracy, miejsca stałego pobytu i wykształcenia [12]. 
Kolejne wyniki badań przeprowadzonych wśród 133 kobiet po amputacji piersi wykazały zależność radzenia sobie ze stresem od wsparcia psychicznego ze strony społeczeństwa. Ponadto czas jaki upłynął od przebytej operacji: trzy miesiące, od trzech do sześciu, od sześciu do dziewięciu i od dziewięciu do roku, w odniesieniu do wszystkich pacjentek korzystnie wpływał na poprawę ich samopoczucia [13].

Wyniki badań R. Stępień oraz G. Wiraszki wskazują na istotną rolę rodziny $\mathrm{w}$ procesie wspierania pacjentek po mastektomii. Zdecydowana większość badanych potwierdziła, że rodzina stanowi dla nich podstawowe źródło oparcia a ich choroba spotkała się w większości z akceptacją przez najbliższych. Chociaż rodzina była podstawowym oparciem, to jednak znacząca grupa respondentek nie rozmawiała ze swoimi krewnymi na temat choroby. Blisko połowa pacjentek nie była zadowolona z pożycia seksualnego (49,4\%). Jednak satysfakcja $\mathrm{z}$ życia rodzinnego korzystnie wpływała na ich stan emocjonalny, codzienne funkcjonowanie i redukcję dolegliwości wynikających z raka piersi [14].

Wyniki badań Z. Musiał i współautorów wskazują, że zdecydowana większość kobiet po mastektomii potwierdziła, że ich życie uległo istotnym zmianom. Tylko nieliczne $\mathrm{z}$ nich nie potwierdziły tego faktu. Większość badanych zaakceptowało utratę piersi. Niezbyt zadowalającym jest fakt, że ponad połowa kobiet nie powróci do pracy zawodowej. Podobna grupa respondentek nie odzyskała po mastektomii pełnej sprawności fizycznej [15].

\section{Wnioski}

1. Zachorowalność i umieralność na raka piersi w Polsce wykazuje tendencję wzrostową.

2. Mastektomia wpływa na istotne zmiany w sferze psychicznego, fizycznego i społecznego funkcjonowania kobiet.

3. Rodzina stanowi główne źródło wsparcia dla pacjentek po usunięciu gruczołu piersiowego. 


\section{Bibliografia/Bibliography:}

1. Tkaczuk-Włach J., Sobstel M., Jakiel G. Rak piersi - znaczenie profilaktyki pierwotnej i wtórnej. Przegląd Menopauzalny. 2012; 16, 4:343.

2. Jeziorski A. Onkologia. Podręcznik dla pielęgniarek. Państwowy Zakład Wydawnictw Lekarskich, Warszawa 2005: 11-101.

3. http://onkologia.org.pl/rak-piersi-kobiet/ dostęp dnia 27.11.2018r.

4. Nowicki A. Pielęgniarstwo onkologiczne. Termedia, Poznań 2009: 20.

5. http://onko-med.pl/nowotwory/czym-jest-czynnik-ryzyka/ dostęp dnia 27.11.2018r.

6. http://onkologia.org.pl/profilaktyka-nowotworowa/.

7. Haor B., Ciechanowska K., Krajewska K., Przystaś B., SanderGrabowska M. Kształtowanie się zachorowalności oraz umieralności spowodowanych chorobami nowotworowymi w Polsce i na świecie. Zbliżenia Cywilizacyjne 2018;XIV(2): 41.

8. https://www.gov.pl/web/zdrowie/narodowy-program-zwalczaniachorob-nowotworowych-na-lata-2016-2024/ dnia 27.11.2018r.

9. https://www.gov.pl/web/zdrowie/profilaktyka-onkologicznaakcja-informacyjna-ministerstwa-zdrowia/ dnia 27.11.2018r.

10. Kózka M., Płaszewska-Żywko Ż. Diagnozy i interwencje pielęgniarskie. Podręcznik dla studiów medycznych. Wydawnictwo Lekarskie PZWL, Warszawa 2015: 261-262.

11. de Walden-Gałuszko K., Ciałkowska-Rysz A. Medycyna paliatywna. Wydawnictwo Lekarskie PZWL, Warszawa 2015: 66. 
12. Pawlik M., Kaczmarek-Borowska B. Akceptacja choroby nowotworowej $\mathrm{u}$ kobiet po mastektomii. Wydawnictwo UR, Rzeszów 2013:203-210.

13. Kasperczyk A. Wsparcie społeczne w instytucjach opieki paliatywnej i hospicyjnej. Wydawnictwo Uniwersytetu Łódzkiego, Łódź 2006: 39.

14. Stępień R., Witaszka G. Znaczenie rodziny w adaptacji funkcjonalnej kobiet po radykalnym leczeniu chirurgicznym raka piersi. Problemy Pielęgniarstwa 2011; 19(3):375-377.

15. Musiał Z., Sendecka W., Zalewska-Puchała J. Jakość życia po mastektomii. Problemy Pielęgniarstwa 2013; 21(1): 38-46. 